\title{
Personality and aggression: A contribution of the General Aggression Model
}

\author{
Personalidade e agressão: uma contribuição \\ do Modelo Geral da Agressão
}

\author{
Jaqueline Gomes CAVALCANTI \\ Carlos Eduardo PIMENTEL ${ }^{2}$
}

\begin{abstract}
The aim of the study was to identify the direct and indirect existing relationship among personality traits on aggression of high school and undergraduate students from the city of João Pessoa, Brazil, using the General Aggression Model as the theoretical framework. The sample consisted of 218 students, of which 107 were high school students and 111 undergraduate students. The instruments used for data collection were as follows: Aggression Questionnaire, the Big Five Inventory and a Socio-Demographic Questionnaire. The main results showed direct effects of neuroticism $(+)$, extraversion (+) and agreeableness (-) in physical aggression. On the other hand, indirect effects of neuroticism (+), opening (+) and agreeableness (-) in physical aggression, mediated by aggressive emotions have been found. These findings are discussed based on previous research and the General Aggression Model along with suggestions of research which have been conducted in an attempt to further knowledge in this area.
\end{abstract}

Keywords: Aggression; Aggressiveness; Aggressive behavior; Personality.

\section{Resumo}

Este estudo objetivou conhecer a relação direta e indireta que há entre os traços de personalidade e a agressão de estudantes do ensino médio e superior da cidade de João Pessoa. Como aporte teórico, foi utilizado o Modelo Geral de Agressão. Contou-se com uma amostra de 218 estudantes, dos quais 107 eram alunos do ensino médio e 111, universitários. Os instrumentos utilizados para a coleta de dados foram os seguintes: o Questionário de Agressão, o Inventário dos Cinco Grandes Fatores de Personalidade e um Questionário Sócio-Demográfico. Os principais resultados mostraram efeitos diretos do neuroticismo (+), extroversão (+) e agradabilidade (-) na agressão física. Verificaram-se, por outro lado, efeitos indiretos do neuroticismo (+), abertura (+) e agradabilidade (-) na agressão física mediadas pelas emoções agressivas. Esses achados são discutidos com base em pesquisa prévia e no Modelo Geral da Agressão e sugestões de pesquisas as quais foram realizadas para se avançar nessa área.

Palavras-chave: Agressão; Agressividade; Comportamento agressivo; Personalidade.

\footnotetext{
$\checkmark \nabla \nabla v$

1 Universidade Federal da Paraíba, Centro de Ciências Humanas, Letras e Artes, Programa de Pós-Graduação em Psicologia Social. Cidade Universitária, s/n., Castelo Branco, 58051-900, João Pessoa, PB, Brasil. Correspondência para/Correspondence to: C.E. PIMENTEL. E-mail: <carlosepimentel@bol.com.br>.

2 Universidade Federal da Paraíba, Centro de Ciências Humanas, Letras e Artes, Departamento de Psicologia. João Pessoa, PB, Brasil.
} 
The study of aggressive behavior has increased in recent years and has attracted the interest of many fields, particularly regarding its nature (Chaves, 2006; DeWall, Anderson, \& Bushman, 2011; Ferreira, 2011; Kristensen, Lima, Ferlin, Flowers, \& Hackmann, 2003).

Human aggression is the result of multiple factors (Anderson \& Bushman, 2001; Kristensen et al., 2003). The General Aggression Model (GAM) describes personality as a key variable for understanding personal factors that influence aggressive behavior. This process occurs by the impact of personality on emotions and aggressive thoughts (Anderson \& Bushman, 2001). In the present study, we will analyze the personality traits that have a greater relationship with aggression. Thus, we chose the Big Five Model of Personality Factors (MPF) as it has been replicated in different cultures and has proved to be appropriate for representing personality constructs (Schmitt, 2008; Schmitt, Allik, McCrae, \& Benet-Martínez, 2007).

\section{Agression}

Aggression and violence are frequently misunderstood terms or considered as synonyms, but they are distinct expressions (Cardoso, 2010; Fiorelli \& Mangini, 2011; Kristensen et al., 2003). Aggression (aggressione) is any behavior directed toward another individual with the intent to harm (Anderson \& Bushman, 2002).

Violence is a subtype of aggression that aims to cause extreme harm among individuals of a particular kind of species: human beings. In this sense, all violence is an aggression, but many instances of aggression are not violent (Anderson \& Bushman, 2002).

The study of human aggression is guided by several theoretical perspectives that emphasize different aspects that range from the social context to strictly biological aspects (Kristensen et al., 2003; Rodrigues, Assmar, \& Jablonski, 2012). These concepts are grouped together into three general explanatory categories: 1) aggression associated with human nature-ethologists and psychoanalysts consider it to be an instinctive concept of aggression to explain it as being originated from innate inner impulses (Kristensen et al., 2003); 2) aggression as a natural response to frustration, as the original concept proposed by John Dollard and subsequent revisions; and 3) learned aggression-theorists of instrumental and observational learning (Rodrigues et al., 2012).

In the 1990s, some theorists sought to develop a theoretical framework that would integrate existing theories of aggression into a unified whole (Kristensen et al., 2003). Among them, we chose the theoretical framework of the General Aggression Model (Anderson \& Bushman, 2002) as the framework for this study.

\section{General Aggression Model}

The General Aggression Model, proposed by Anderson and Bushman (2002), is the result of endeavors to integrate existing theories of aggression, such as the Social Learning Theory of Bandura (1977); Cognitive Neoassociation Theory of Berkowitz (1993) and the Social Interaction Theory of Tedeschi and Felson (1994). In this sense, the GAM is a more parsimonious model of aggression than other theories that explain this phenomenon and it offers ways to reduce aggressive behavior (DeWall et al., 2011).

This model proposes that aggressive behavior is based on the three following knowledge structures: perceptual schemata, which are used to identify phenomena as simple as everyday physical objects or as complex as social events, for example, social insult; personal schemata, which include beliefs about a particular person or groups of people; and behavioral scripts, which contain information about how people behave under varying circumstances (Anderson \& Bushman, 2002; Cardoso, 2010).

These structures are developed out of the experience of individuals and influence the perception of individuals at multiple levels, from basic visual patterns to complex behavioral sequences. However, as they are being used, they tend to become automatized because they remain 
associated with affective states and guide people's interpretations and their behavioral responses to the environment (Anderson \& Bushman, 2002).

Anderson and Bushman (2002) report that the model focuses on the person in the situation, called an episode. Therefore, the central foci of the model are: 1) person input, including: traits, beliefs, gender, attitudes, values, among others; and situation input, situational factors including media, frustration, drugs, provocation etc; 2) cognitive, affective and arousal routes of the current internal state; and 3) outcomes of the appraisal (immediate or automatic, secondary or controlled) and decision process.

Currently, studies using the GAM have shown that this model is well suited to explain the effects of media exposure on aggressive behavior (Adachi \& Willoughby, 2011; Anderson \& Bushman, 2001). Nevertheless, the GAM has also provided useful findings for understanding changes in violent attitudes toward war (Carnagey \& Anderson, 2007), the effect of attention and impulsivity problems in aggressive behavior (Swing \& Anderson, 2014), and even the relationship between personality and aggression (Barlett \& Anderson, 2012; Housie, Gilbert, Simpson, \& Daffern, 2013).

\section{General Aggression Model and aggression}

Some theorists argue that personality variables are important predictors of aggressive behavior (Anderson \& Bushman, 2002; Carvalho \& Nobre, 2013; Jones, Miller, \& Lynam, 2011; Lau, 2013). Currently, the most common approach used to explain personality in empirical research is the GAM (Housie et al., 2013; McCrae \& Costa Jr., 2004).

For a long time, the study of personality has been handicapped due to the lack of a systematic taxonomy of constructs to represent individual differences. However, this situation began to change when some of the main dimensions of personality were agreed upon: traits such as neuroticism, extraversion and introversion. Within this framework, further psychometric studies and personality inventories have identified five major factors
(McCrae \& Costa Jr., 1985) namely, agreeableness, extraversion, conscientiousness, neuroticism and openness, and evidence of these have been found in Brazil (Hutz et al., 1998; Nunes \& Hutz, 2007; Santos, Sisto, \& Martins, 2003).

The Agreeableness dimension (Factor I) has often been associated with aggressive behavior (Gleason, Jensen-Campbell, \& Richardson, 2004; Jones et al., 2011; Jovanovic, Lipovac, Stanojevic, \& Stanojevic, 2011; Lee \& Egan, 2013; Miller, Zeichner, \& Wilson, 2012). Agreeableness (Factor I) refers to behaviors directed toward the needs of others, including aspects such as trust, honesty, altruism, among others (Bettencourt, Talley, Benjamin, $\&$ Valentine, 2006). This dimension is related to the maintenance of positive interpersonal relationships and minimization of conflicts (Benet-Martínez \& John, 1998). For example, Miller et al. (2012) conducted a study to assess the association between the dimensions of the GAM and aggression. The results showed that the Agreeableness factor was negatively related with aggressive behavior.

Theories and studies also suggest that there is a strong connection between aggression and the Neuroticism factor (Bettencourt et al., 2006; Kamaluddin, Shariff, Ismail, Saat, \& Othman, 2014; Lee \& Egan, 2013; Michel \& Bowling, 2013). In a study conducted by Sharpe and Desai (2001), the Neuroticism factor was positively related to aggressive behavior, whereas the Conscientiousness dimension was negatively associated with aggression. The Neuroticism dimension (Factor II) is connected to the characteristics of people prone to psychological distress, which tend to have unrealistic ideas and low tolerance for frustration and suffer from anxiety, depression, hostility, impulsivity, self-criticism, and vulnerability. The Conscientiousness factor (Factor III) is related to the degree of persistence, control, organization and motivation of the individual to achieve goals (Benet-Martínez \& John, 1998). In this research, extraversion was negatively correlated with aggressive behavior. Extraversion (Factor IV) is related to positive emotions and sociability (BenetMartínez \& John, 1998).

In an endeavor to understand the relationship between the GAM and physical aggression and 
whether these have direct and/or indirect effects on aggressive attitudes and emotions (integrating hostility and anger), Bartlett and Anderson (2012) concluded a survey with 1,220 college students. The results showed that the Openness and Agreeableness factors were directly and indirectly related to physical aggression, but were only indirectly associated with aggressive attitudes and violent behavior. The Openness factor (Factor $\mathrm{V}$ ) is related to giving importance to new experiences and exploratory behavior. People who obtain high scores on this factor tend to prefer new activities and emotions (Benet-Martínez \& John, 1998). The Neuroticism dimension was directly and indirectly related - via aggressive emotions - to physical aggression, but not to violent behavior.

The General Aggression Model is related to aggressive behavior because such factors may enhance or inhibit access to aggressive emotions, aggressive attitudes and their development (Bartlett \& Anderson, 2012). This would take place as follows: repeated exposure to stimuli and situations related to aggression would be related to emotions and aggressive attitudes and consequently, would be related to the risk of aggressive behavior manifestation (Anderson \& Bushman, 2002).

A recent survey was conducted with a sample of offenders and the results showed that the Agreeableness and Conscientiousness factors were significant predictors of an aggressive life history (Housie et al., 2013). Once again, this shows the importance of the five major personality factors for the understanding aggression. Although some studies emphasize the relationship between personality traits and aggression, no studies relating GAM with aggression were found in Brazil. The lack of research encouraged the present study.

Based on General Aggression Model, we outlined the model with five personality factors as predictors of physical aggression and aggressive emotions as a mediator variable. Therefore, we intend to replicate the study of Bartlett and Anderson (2012). This model can be seen in Figure 1 and the aim of the study was to test the model. According to our review, these are the first empirical

\section{Method}

\section{Participants}

This is a convenience (non-probabilistic) sample consisting of 218 people. Of the total sample, 111 were students of a public university and 107 high school seniors from a public school in João Pessoa. The mean age of participants was 18.87 years (Standard Deviation $-S D=3.44$ ) with a predominance of women $(58.7 \%)$.

\section{Instruments}

The participants answered the following instruments:

The Aggression Questionnaire: The instrument was developed by Buss and Perry (1992) and it consists of 29 items that assess four factors, namely: physical aggression (e.g., If someone hits me, I will hit back); verbal aggression (e.g., I cannot remain silent when people disagree with me); anger (e.g., Some of my friends say I am explosive); and hostility (e.g., Sometimes jealousy eats me up inside). These items were answered on a five-point scale Likert scale, ranging from 1 = Strongly Disagree to $5=$ Strongly Agree. In Brazil, the adaptation of the instrument was presented by Gouveia, Chaves, Peregrino, Branco, and Gonçalves (2008) and it showed good indicators of internal consistency. The alpha coefficients found by these authors were as follows: physical aggression $(\alpha=0.85)$, verbal aggression ( $\alpha=0.72)$, anger $(\alpha=0.83)$ and hostility $(\alpha=0.77)$. The general factor showed an alpha coefficient of 0.89 . In the present study, the following reliability coefficients were found: physical aggression $(\alpha=0.75)$, verbal aggression $(\alpha=0.60)$, anger $(\alpha=0.80)$ and hostility $(\alpha=0.69)$.

Inventory of the Big Five Personality Factors (Big Five Inventory - BFI): It was first developed in English by John, Donahue, and Kentle (1991) and validated in Brazil by Andrade (2008). We used the 34-item version, which corresponds to five factors, namely: Openness; Conscientiousness; Extraversion; Agreeableness and Neuroticism. To answer the 
questionnaire, the participants would indicate on a Likert scale the attributes that best described them, as follows: $1=$ Strongly Disagree to $5=$ Strongly Agree. In the validation study, the BFI presented the following reliability coefficients: Openness ( $\alpha=0.65)$, Neuroticism $(\alpha=0.75)$, Extraversion ( $\alpha=0.75)$, Conscientiousness $(\alpha=0.65)$ and Agreeableness $(\alpha=0.69)$. In the present study, we found the following reliability coefficients in the BFI factors: Agreeableness $(\alpha=0.71)$; Extraversion $(\alpha=0.83)$; Conscientiousness $(\alpha=0.51)$; Openness $(\alpha=0.74)$ and Neuroticism $(\alpha=0.80)$.

Socio-demographic questionnaire: Some data were also obtained to characterize the respondents, such as: age, sex, social class, grade, course, level of religiosity and marital status; in addition to the Term of Free and Informed Consent, according to Resolution $n^{\circ} 466 / 2012$ (Brasil, 2012).

\section{Procedures}

To collect the data at the university, participants completed the questionnaires individually, but in collective environment, that is, in the classroom. Before conducting the study, the professor of the subject was contacted and, after obtaining consent, the researcher introduced herself and invited the college students to collaborate with the research. The researcher assured the students that their answers were confidential. Participants who agreed to participate in the study signed the informed consent form. The completion of questionnaires lasted approximately 15 minutes.
Data collection at the schools took place as follows: first we obtained permission from the school principal. After obtaining consent, the application of the questionnaires was conducted. The classes were chosen by the researcher based on the availability of teachers and classes and the application occurred in a collective environment, that is, in the classroom. The researcher presented the study and students were asked to participate. The researcher instructed them to answer the questionnaire individually. The average time for students to answer the questionnaire was 15 minutes. The project was approved by the Ethics Committee of the Federal University of Paraíba (Process $n^{\circ} 27743214.1 .0000 .5188$ on July 18 , 2014).

\section{Results}

Initially, a correlation analysis with the study variables, namely, the five personality factors, aggressive emotions and physical aggression was performed. These relationships are shown in Table 1.

According to the results shown in Table 1, physical aggression proved to be positively correlated with Neuroticism $(r=0.34 ; p<0.01)$ and Extraversion $(r=0.13 ; p<0.05)$ and negatively with Agreeableness $(r=-0.24 ; p<0.01)$. We observed statistically significant correlations between Aggressive emotions (anger + hostility) and personality. Particularly, Aggressive Emotions were positively related to Neuroticism $(r=0.62 ; p<0.01)$ and negatively to Conscientiousness $(r=-0.17 ; p<0.05)$.

Table 1

Correlation between the Big Five factors of personality and aggression factors. João Pessoa (PB), 2014

\begin{tabular}{|c|c|c|c|c|c|c|c|c|c|}
\hline Variables & $M$ & $S D$ & & & & & & & \\
\hline Neuroticism & 4.2 & 0.66 & & & & & & & \\
\hline Agreeableness & 3.1 & 0.83 & -0.08 & & & & & & \\
\hline Extraversion & 3.0 & 0.57 & -0.00 & 0.25 & & & & & \\
\hline Openness & 3.7 & 0.62 & 0.02 & 0.27 & 0.22 & & & & \\
\hline Conscientiousness & 3.0 & 0.96 & -0.27 & 0.29 & 0.14 & 0.20 & & & \\
\hline \multirow[t]{2}{*}{ Physical aggression } & 2.7 & 0.77 & $0.34^{* *}$ & $-0.24^{* *}$ & $0.13^{*}$ & 0.03 & -0.12 & 0.62 & \\
\hline & & & 1 & 2 & 3 & 4 & 5 & 6 & 7 \\
\hline
\end{tabular}

Note: ${ }^{*} p<0.05,{ }^{* *} p<0.01$ (One-tailed test).

M: Mean; SD: Standard Deviation. 
To analyze the mediation model in this study, we first analyzed the direct effects of the Big Five personality factors on physical aggression, as recommended by the literature (Preacher \& Hayes, 2004). We conducted a path analysis and bootstrap using 5000 simulations from a database with 218 subjects. Standardized direct effects of Neuroticism (0.32, 90\% Confidence Interval $-\mathrm{Cl}=0.21,0.42$, $p<0.001)$, Extraversion $(0.19,90 \% \mathrm{Cl}=0.08,0.29$, $p<0.002)$ and Agreeableness $(-0.28,90 \% \mathrm{Cl}=-0.38$,

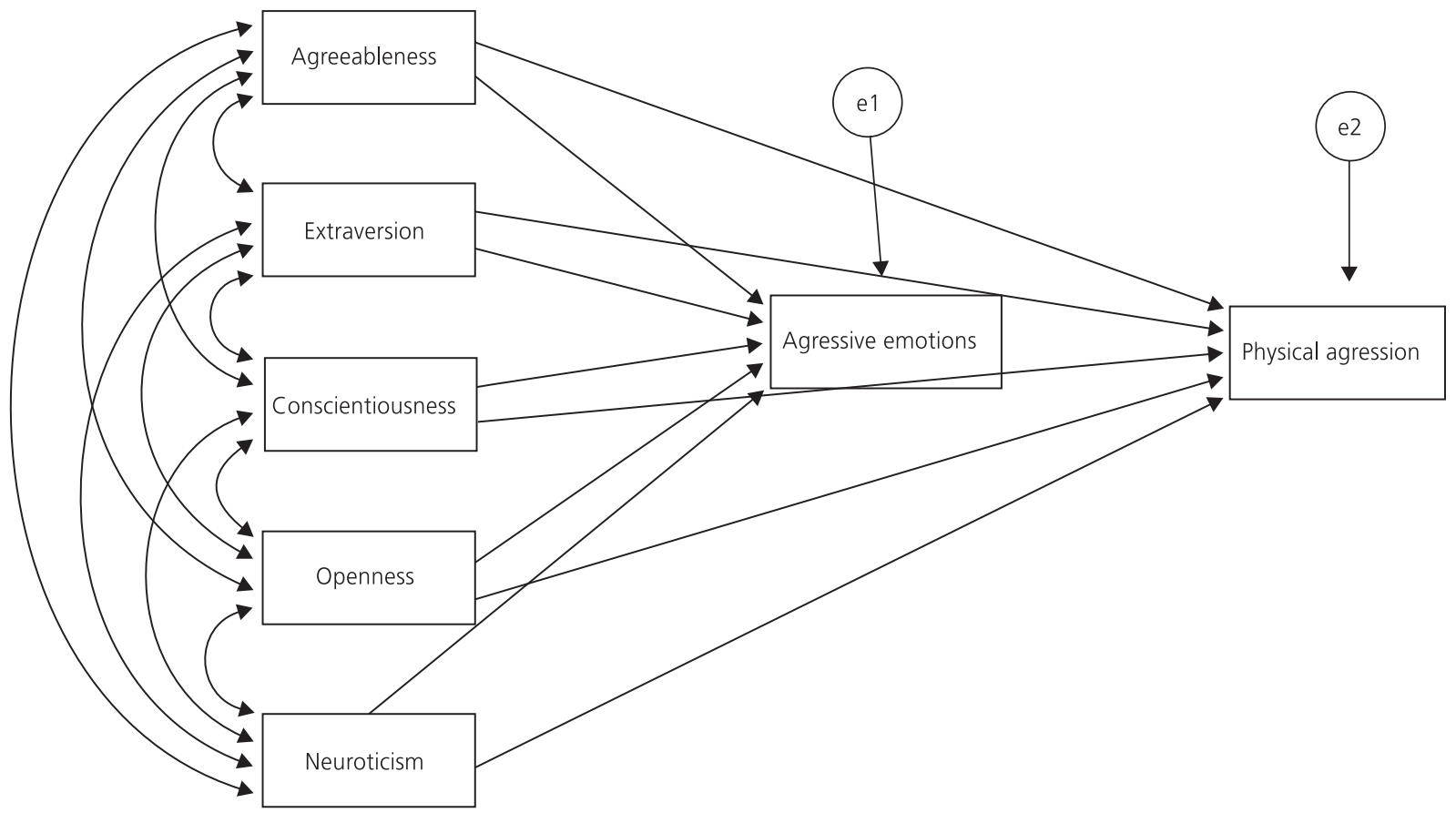

Figure 1. Mediation model proposed of personality and aggression traits.

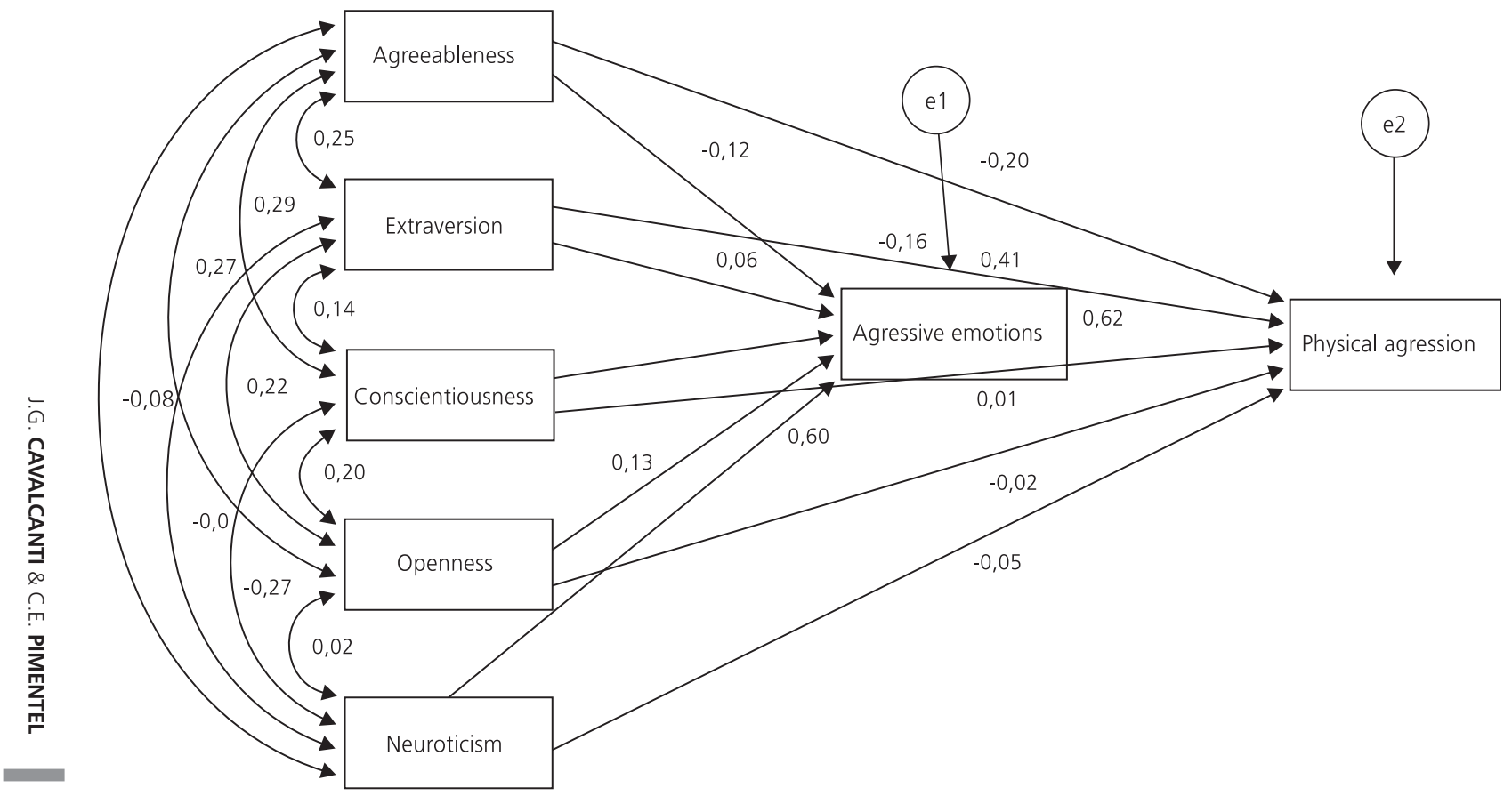


$-0.16, p<0.001)$ were observed on physical aggression. The Openness to Change and Conscientiousness factors showed no statistically significant effects.

A new analysis was later performed with the mediating variable 'aggressive emotions'. Standardized indirect effects of Neuroticism (0.38, $90 \% \mathrm{Cl}=0.30,0.46, p<0.001)$, Openness $(0.08$, $90 \% \mathrm{Cl}=0.03,0.14, p<0.02)$ and Agreeableness $(-0.08,90 \% \mathrm{Cl}=-0.14 ;-0.02, p<0.03)$ were observed on physical aggression. As expected, Neuroticism was positively related to physical aggression, and Agreeableness was negatively related.

In order to verify the type of mediation, standardized direct effects of predictive variables were observed. Particularly, complete mediation was observed in the case of Neuroticism because its standardized direct effect was no longer statistically significant with the mediating input; and partial mediation was found in the case of Agreeableness, as its standardized direct effect was still statistically significant with the mediating input. In the case of Openness to Change, the indirect effects of this factor did not have a direct effect on aggression at first. Figure 2 shows the model tested in this study and the standardized total effects.

Finally, according to the analysis performed, in general, the model used in this study is adequate, that is, favorable empirical evidence was found regarding the use of GAM in our country.

\section{Discussion}

The aim of the present research was to verify the direct effects of the five major personality factors on physical aggression and aggressive emotions (Anderson \& Bushman, 2002) as well as the indirect effects on physical aggression, according to the mediation model based on GAM (Bartlett \& Anderson, 2012). We believe that our goal has been achieved.

When considering the correlations between the five factors of personality and aggression found in this study, there were significant positive relationships between Neuroticism and the factors
Physical Aggression and Aggressive Emotions. Thus, people who obtained high scores on neuroticism are more likely to present aggressive emotions and aggressive behavior. A negative association was found between Agreeableness and Physical Aggression; i.e. the higher the score for Agreeableness, the lower will be the score for aggression. Therefore, the results corroborate the findings of previous studies (Bettencourt et al., 2006; Gleason et al., 2004; Jones et al., 2011; Jovanovic et al., 2011). On the other hand, the positive correlation between Extraversion and Physical Aggression does not confirm the findings of previous studies (Sharpe \& Desai, 2001; Bartlett \& Anderson, 2012). Thus, further studies are needed to reanalyze this relationship.

Taking into account the theoretical framework used in this research, which describes personality as a predictor of aggressive behavior (GAM, Anderson \& Bushman, 2002), we assessed the mediating role of aggressive emotions in the Brazilian context. Our results corroborate the findings of Bartlett and Anderson (2012) who found that Neuroticism is related in a direct or mediated way by aggressive emotions to physical aggression. Similarly, the Agreeableness and Physical Aggression factors would be directly and indirectly related. In this regard, certain personality traits indicate greater or lesser inclination to aggressive emotions that, in turn, influence aggressive behavior. These effects therefore exert an impact on decision making in accordance with GAM (Anderson \& Bushman, 2002)

It is noteworthy that we found indirect effects of Openness on Aggressive Behavior, which is not in agreement with the research by Bartlett and Anderson (2012), which shows a non-significant relationship. The data therefore deserves more attention in future studies. Despite these results, it is essential to point out some limitations of the present study. The first one is that the study did not include more variables, such as, for example, violent behavior (Barlett \& Anderson, 2012).

Due to the lack of research support in the country, many volunteers refused to answer the longer questionnaires. That is, participants are not 
paid or acknowledged for participating in studies, which could decrease their interest to participate. Another limitation worth mentioning was that the sample was composed exclusively of students. Further studies could include people from the general population who are not studying or who have completed their education.

Moreover, it is believed that research on aggression based on this theory may reduce violence in society (DeWall et al., 2011). Therefore, further studies would be important if other variables deemed important by the GAM in predicting aggressive behavior were included, such as some situational variables, for example, violent media. Furthermore, we suggest that further research should be conducted to verify the influence of these variables.

In short, the theoretical framework was assessed and favorable evidence was found. It may be concluded that the GAM is a useful framework for understanding the phenomenon of aggression. Knowing if there are certain traits that predispose some individuals, more than others, to resort to aggression is an effective form of prevention and minimization of aggressive behavior. Furthermore, studying aggressive personality can help control aggression by identifying aggressive profiles. We hope further research can be carried out in other contexts to replicate our findings in order to further the knowledge about personalities, particularly regarding behaviors related to aggression.

\section{Contributors}

All authors contributed to the conception and design of the study, data analysis and final editing.

\section{References}

Adachi, P. J. C., \& Willoughby, T. (2011). The effect of violent video games on aggression: Is it more than just the violence? Aggression and Violent Behavior, 16(1), 55-62. http://dx.doi.org/10.1016/j.avb.2010. 12.002

Anderson, C. A., \& Bushman, B. (2001). Effects of violent video games on aggressive behavior, aggressive cognition, aggressive affect, physiological arousal, and pro- social behavior: A meta-analytic review of the scientific literature. Psychological Science, 12(5), 353-359.

Anderson, C. A., \& Bushman, B. (2002). Human aggression. Annual Review of Psychology, 53(1), 27-51.

Andrade, J. M. (2008). Evidências do inventário dos cinco grandes fatores de personalidade para o Brasil (Tese de doutorado não-publicada). Universidade de Brasília.

Bandura, A. (1977). Social learning theory. Englewood Cliffs: Prentice-Hall.

Barlett, C. P., \& Anderson, C. A. (2012). Direct and indirect relations between the big 5 personality traits and aggressive and violent behavior. Personality and Individual Differences, 52(8), 870-875. http://dx. doi.org/10.1016/j.paid.2012.01.029

Benet-Martínez, V., \& John, O. P. (1998). Los cinco grandes across cultures and ethnic groups: Multitrait multimethod analyses of the big five in Spain and English. Journal of Personality and Social Psychology, 75(3), 729-750.

Berkowitz, L. (1993). Aggression: Its causes, consequences, and control. New York: McGraw-Hill.

Bettencourt, B. A., Talley, A., Benjamin, A. J., \& Valentine, J. (2006). Personality and aggressive behavior under provoking and neutral conditions: A meta-analytic review. Psychological Bulletin, 32(5), 751-777. http:// dx.doi.org/10.1037/0033-2909.132.5.751

Brasil. Ministério da Saúde. (2012) Resolução n 466, de 12 de dezembro de 2012. Recuperado em julho 13, 2014 de http://conselho.saude.gov.br/resoluções/ 2012/reso466.pdf

Buss, A. H., \& Perry, M. (1992). The aggression questionnaire. Journal of Personality and Social, 63(3), 452-459.

Cardoso, J. E. Q. (2010). Personalidade e agressividade: um estudo em militares de proteção e socorro (Dissertação de mestrado não-publicada). Universidade Lusófona Humanidades e Tecnologias, Lisboa, Portugal

Carnagey, N. L., \& Anderson, C. A. (2007). Changes in attitudes towards war and violence after september 11, 2001. Aggressive Behavior, 33(2), 118-129. http:// dx.doi.org/10.1002/ab.20173

Carvalho, J., \& Nobre, O. J. (2013). Five-factor model of personality and sexual aggression. International Journal of Offender Therapy and Comparative Criminology, 20(10), 1-18. http://dx.doi.org/10.1177/ $0306624 \times 13481941$

Chaves, C. M. C. M. (2006). Compromisso convencional: fator de proteção para as condutas agressivas, anti-sociais e de uso de álcool? (Dissertação de mestrado não-publicada). Universidade Federal da Paraíba, João Pessoa.

DeWall, C. N., Anderson, C. A., \& Bushman, B. J. (2011). The general aggression model: Theoretical extensions to violence. Psychology of Violence, 1(3), 245-258. http://dx.doi.org/10.1037/a0023842 
Ferreira, A. S. M. A. (2011). O papel da personalidade no comportamento agressivo: da teoria à a avaliação (Dissertação de mestrado não-publicada). Universidade de Lisboa, Portugal.

Fiorelli, J. O., \& Mangini, R. C. R. (2011). Psicologia jurídica. São Paulo: Atlas.

Gleason, K. A., Jensen-Campbell, A., \& Richardson, D. S. (2004). Agreeableness as a predictor of aggression in adolescence. Aggressive Behavior, 30(1), 43-61. http:// dx.doi.org/10.1002/ab.20002

Gouveia, V. V., Chaves, C. M. C. M., Peregrino, R. R., Branco, A. O. C., \& Gonçalves, M. P. (2008). Medindo a agressão: o Questionário de Buss-Perry. Arquivos Brasileiros de Psicologia, 60(3), 92-103.

Housie, J., Gilbert, F., Simpson, K., \& Daffern, M. (2013). An examination of the relationship between personality and aggression using the general aggression and five factor models. Aggressive Behavior, 40(2), 189-196. http://dx.doi.org/10.1002/ ab.21510

Hutz, C. S., Nunes, C. H., Silveira, A. D., Serra, J., Antón, M., \& Wieczonek, L. S. (1998). O desenvolvimento de marcadores para a avaliação da personalidade no modelo dos cinco grandes fatores. Psicologia: Reflexão e Crítica, 11(2), 395-410.

John, O. P., Donahue, E. M., \& Kentle, R. L. (1991). The Big Five Inventory-Versions $4 \mathrm{a}$ and 54. Berkeley: University of California, Institute of Personality and Social Research.

Jones, S. E., Miller, J. D., \& Lynam, D. R. (2011). Personality, antissocial behavior, and aggression: A meta-analytic review. Journal of Criminal Justice, 39(4), 329-337. http://dx.doi.org/10.1016/j.jcrimjus.2011.03.004

Jovanovic, D., Lipovac, K., Stanojevic, P., \& Stanojevic, D. (2011). The effects of personality traits on drivingrelated anger and aggressive behaviour in traffic among Serbian drivers. Transportation Research Part F: Traffic Psychology and Behaviour, 14(1), 43-53. http://dx.doi.org/10.1016/j.trf.2010.09.005

Kamaluddin, M. R., Shariff, N. S. M., Ismail, K. H., Saat, G. A. M., \& Othman, A. (2014). Associations Between Personality Traits And Aggression Among Malay Adult Male Inmates In Malaysia. ASEAN Journal of Psychiatry, 15(2), 176-185.

Kristensen, C. H., Lima, J. S., Ferlin, M., Flores, R. Z., \& Hackmann, P. H. (2003). Fatores etiológicos da agressão física: uma revisão teórica. Estudos de Psicologia (Natal), 8(1), 175-184.

Lau, K. S. L. (2013). Big five personality traits, pathological personality traits, and psychological dysregulation: Predicting aggression and antisocial behaviors in detained adolescents (Master's thesis unpublished). University of New Orlean, Louisiana.

Lee, V., \& Egan, V. (2013). Predictors of aggression in Southeast Asian female prisoners. Personality and Individual Differences, 54(1), 113-117. http://dx.doi. org/10.1016/j.paid.2012.08.024
McCrae, R. R., \& Costa Jr., P. T. (1985). Updating norman's "adequate taxonomy": Intelligence and personality dimensions in natural language and in questionnaires. Journal of Personality \& Social Psychology, 49(3), 710-721.

McCrae, R. R., \& Costa Jr., P. T. (2004). A contemplated revision of the NEO Five-Factor Inventory. Personality and Individual Differences, 36(3), 587-596.

Michael, J. S., \& Bowling, N. A. (2013). Does dispositional aggression feed the narcissistic response? The role of narcissism and aggression in the prediction of job attitudes and counterproductive work behaviors. Journal of Business and Psychology, 28(1), 93-105. http://dx.doi.org/10.1007/s10869-012-9265-6

Miller, J. D., Zeichner, A., \& Wilson, L. F. (2012). Personality correlates of aggression: Evidence from measures of the five-factor model, UPPS model of impulsivity, and BIS/BAS. Journal of Interpersonal Violence, 20(10), 1-17. http://dx.doi.org/10.1177/0886260512438279

Nunes, C. H. S., \& Hutz, C. S. (2007). Construção e validação da escala fatorial de socialização. Psicologia: Reflexão e Crítica, 20(1), 20-25.

Preacher, K. J., \& Hayes, A. F. (2004). SPSS and SAS procedures for estimating indirect effects in simple mediation models. Behavior Research Methods, Instruments, and Computers, 36(4), 717-731.

Rodrigues, A., Assmar, E. M. L., \& Jablonski, B. (2012). Psicologia social. Petrópolis: Vozes.

Santos, A. A. A., Sisto, F. F., \& Martins, R. M. M. (2003). Estilos cognitivos e personalidade: um estudo exploratório de evidências de validade. Psico-USF, 8(1), 11-19.

Schimitt, D. (2008). Big five traits related to short-term mating: From personality to promiscuity across 46 nations. Evolutionary Psychology, 6(2), 246-282.

Schimitt, D., Allik, J., McCrae, R., \& Benet-Martínez, V. (2007). The geographic distribution of big five personality traits: Patterns and profiles of human selfdescription across 56 nations. Journal of Cross-Cultural Psychology, 38(2), 173-212. http://dx.doi.org/10. $1177 / 0022022106297299$

Sharpe, J. P., \& Desai, S. (2001). The revised neo personality inventory and the MMPI-2 psychopathology five in prediction of aggression. Personality and Individual Differences, 31(4), 505-518.

Swing, E. L., \& Anderson, C. A. (2014). The role of attention problems and impulsiveness in media violence effects on aggression. Aggressive Behavior, 40(3), 197-203. http://dx.doi.org/10.1002/ab.21519

Tedeschi, J. T., \& Felson, R. B. (1994). Violence, aggression, and coercive actions. Washington: American Psychological Association.

Received: August 15, 2014

Final version: March 9, 2015

Approved: March 26, 2015 
